\title{
Indonesian director Garin Nugroho
}

\author{
By Jan Uhde \\ Spring 1999 Issue of KINEMA
}

\section{INDONESIAN DIRECTOR GARIN NUGROHO IN CONVERSATION WITH KINEMA}

YOGYAKARTA, a peaceful three-quarter-million Central Javanese city surrounded by picturesque volcanoes is not only renowned as a centre for tertiary education in Indonesia but it is also reputed to be the country's cultural capital. Just kilometres away, two fabulous historical monuments more than a thousand years old -the Borobudur and the Prambanan -- attract tourists from all over the world to the region.

But there is another side to this benevolent image. Thousands live in poverty there, among them many children -- the street children of Yogya. Their sad and often short lives became the focus of the Indonesian director Garin Nugroho's 1998 semi-documentary feature Leaf on a Pillow (Daun di atas bantal), "a discovery of the Cannes 1998 festival" (Positif), which won for the 38-year film-maker several international awards including Best Film and Best Actress for Christine Harkim at the Asia-Pacific FF, Taipei 1998 and The Jury Award at the Tokyo FF.

KINEMA: Is Leaf On a Pillow your first film on street children in Indonesia?

Garin Nugroho: Yes, this is my first film on this subject and its screenplay is based on a true story. We researched the subject on street children with three specialists, one of the from the faculty of Psychology, one from Sociology, and another from the Faculty of Film. It was a multi-discipline approach. Some of the research was done in libraries but the most important part was taken directly from everyday life through our interaction with them. For example, the kids wore very long, extra large T-shirts. We wanted to exchange them for more fitting ones but they refused, they said they liked it that way. It was because the oversized T-shirts were more practical for them and at night they could be used like blankets.

Or the way they kept their money stuffed into the jacket collar or their cuffs; if they held it in their hands, it would be stolen. All the details, the body language and other aspects of their lives had to be researched. Or when the people sell their becak, we had to know how they tie it with the string. This all was used in the film.

How did you succeed in making the children behave so naturally in front of the camera?

The non-professional actor, like the street children, can express himself well if what I call the macrosystem, the atmosphere, is right for them. It is as if they were acting in their own house. If I am in my house, I can express myself better. The acting is the microsystem and the atmosphere is the macrosystem. For example the farmer can express himself better if he goes into the field, into his rice-paddies. We tried to make the atmosphere for children like the rice-paddies for the farmer. Many film-makers tried to deal with the non-professional actors on the micro-level, the acting only. The acting is the balance between the body language and the oral expression. And we created the right environment for the children to act when we became friends with them in their ordinary life.

How was the script for the film written? It feels almost like a documentary.

The person's acting depends on three different aspects which we have to keep in mind: the intellectual, the character, and the particular body language of an individual. For example, in the film, Heru is a strong character. He is already more mature so his acting is consistent. But he also gets more easily angry in everyday life. Sugen tends to talk a lot. And Kancil, he says little and his face evokes sympathy but he is not consistent enough. Of course the script was only a draft. Initially, I planned for Kancil to be the leading character but after I became familiar with the children, I changed it.

I heard that some of the children from your film later died.

One of the children died after I made the documentary, and another one got lost, I don't know where. If you remember the film, they get drunk, they want to go to another city, they climb on the top of a train and you can imagine what can happen. Also, there is the possibility of the insurance mafia who murder street kids after they make them sign life insurance policies and then cash the insurance money. 


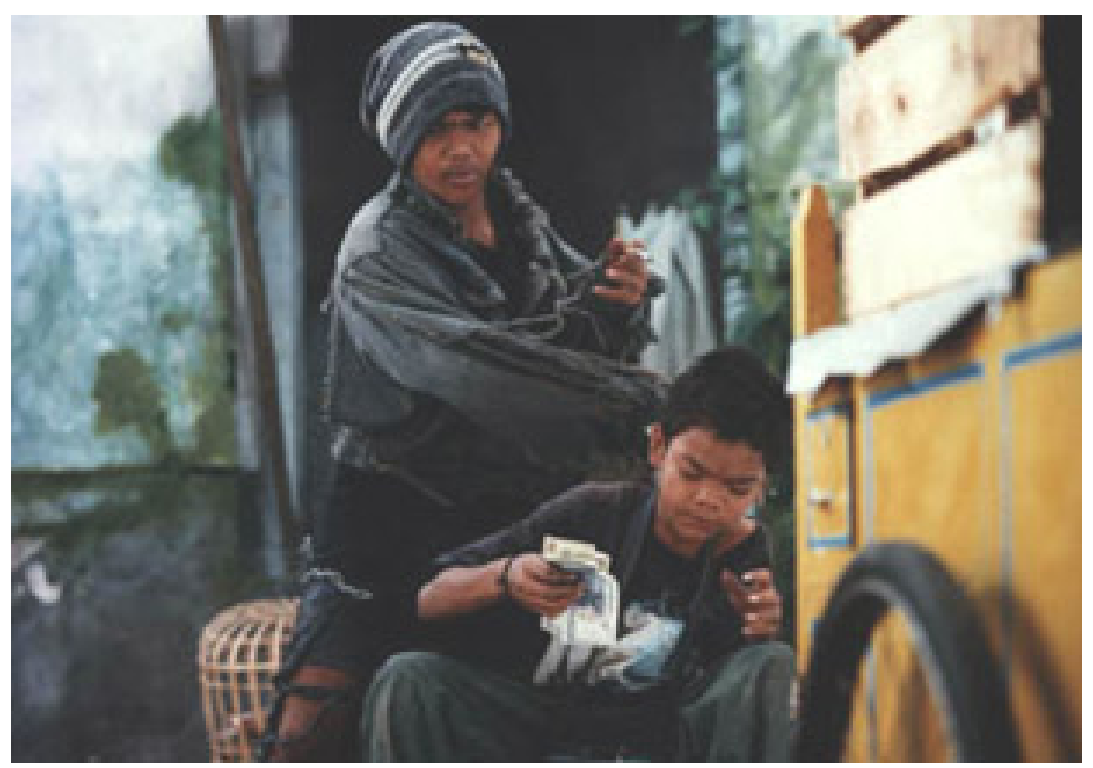

Figure 1: Street children from the Leaf on a Pillow

\section{Can you tell us a little about yourself?}

I was born in Yogyakarta. My father was a book publisher there and my mother worked in the post office. Almost all my family members are artists: one of them is a pottery artist, one a sculptor, one is a sociologist and most of the others are teachers. I attended a Muslim elementary school, then the Loyola Catholic school. Finally, I went to the Film School and later studied Law at the University -- four years in each. I practised law for one year and now I am teaching Film at the Jakarta Institute of the Arts.

Did the fact that you were born in Yogyakarta influence the choice of city for your film?

Of course -- I know exactly how the street children live because I used to know the city perhaps even better than them, even though I come from a different social background. When I was a child I was sometimes naughtier than the street kids!

Your Leaf On a Pillow is quite critical socially, did you have any difficulties with the censorship?

It is only by accident that this film can be shown. We made the film before the fall of Suharto regime (1998) but it was released after Suharto's fall. That changed the situation. I told to my distributor: "If you won't support me and won't show my film, you'll have a problem." They were afraid I would organise a demonstration or something like that and so the film was released in Indonesia. It became quite famous and even a box-office hit.

\section{Why did you call the film Leaf on a Pillow?}

The name was actually inspired by a beautiful photo of a leaf on a woman's breast but I changed the title to "Leaf On a Pillow." For me, a leaf is something special: people think it is insignificant; they throw it away, walk on it but it is very useful for our lives, it is the life of trees. And a pillow is something for us to sleep, dream and cry on and also hide money in...

\section{What is it that the censors don't like in your films?}

They don't want the film to criticise the bureaucracy and the government system. These are untouchable subjects. For example, in Indonesia you cannot criticise the courts.

How would you describe your film-making style in the Leaf On a Pillow?

I don't know but the film was very controversial in Indonesia. When I screened it, some critics said: "Garin Nugroho should go back to film school!" They said that my approach was totally wrong. In fact, I had used several different approaches. The important thing for me was the idea. If you had an idea, you looked for the best way to express it. I wasn't concerned with any particular "style." 


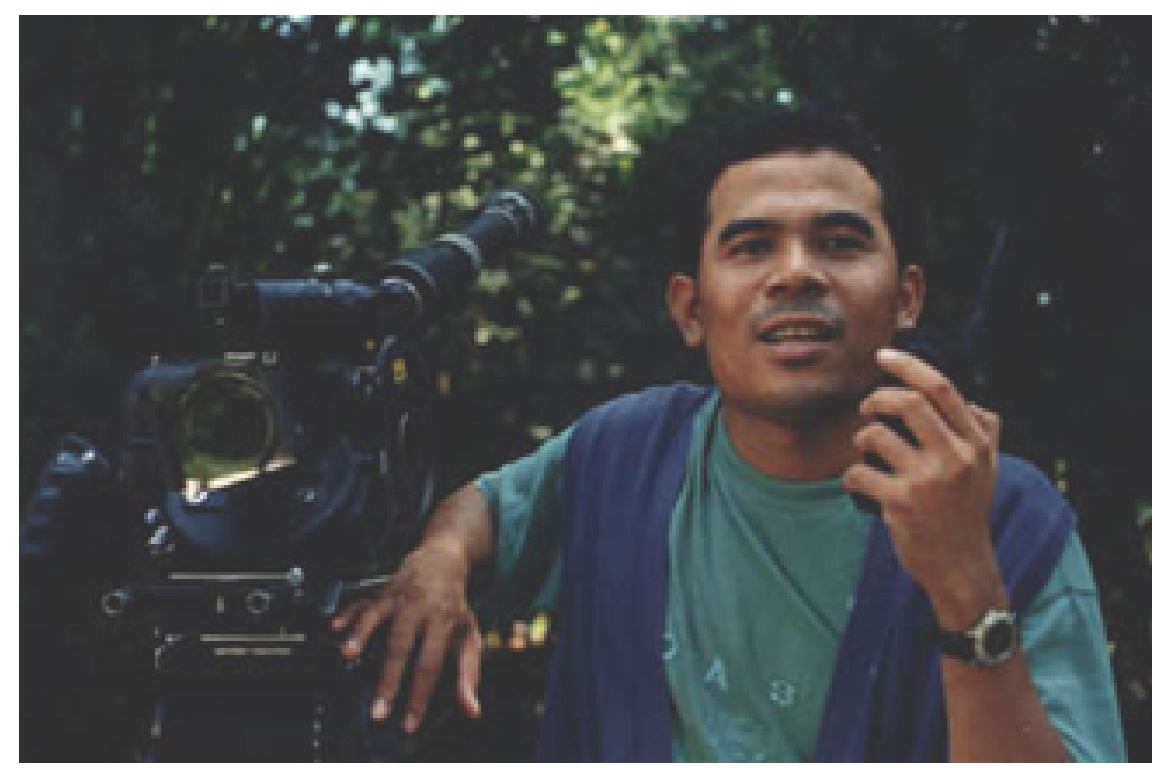

Figure 2: Director Garin Nugroho

How much did the Leaf cost to make and how did you get the money for it?

It cost 2 billion Indonesian Rupiah, or approximately US $\$ 200,000$ (at that time 1 US $\$$ was about 10,000 Rupiah). Some funds came from private sources, some came from the Hubert Bals Fund in the Netherlands which has been supporting the production of films in developing countries, others from Japan.

You also mentioned that some of the raw footage was lost. What happened actually?

Our camera's gate was damaged but you couldn't see it on the monitor. That was the time of the economic crisis and the producer was forced to make new negotiations with the laboratories in Australia. And as the Rupiah plunged, everything suddenly became five times more expensive. How can you make a deal under such circumstances? We had to re-shoot 99 per cent of the film again. It was an expensive "rehearsal"!

\section{What kind of films do you wish to make?}

I like to make films that provoke discussion -- whether about the content or style. For example I would like to make a Muslim film about sex, with nudity. I am bored with the depiction of drunkenness in my country. Religion is intertwined with many aspects of life -- with sex, with politics, everything. And now there is maybe more room to raise these issues in Indonesia. But it is still difficult and my producer always says: "Do you want to kill me, Garin?" The money is there but the problem is that the issue makes the producer afraid. For my next film, I am thinking about two topics: A military scandal in Aceh (North Sumatra) or a Muslim love affair.

Finally, what is your main concern regarding Indonesian cinema today?

If, for many years, you use the media only for propaganda, it creates a very difficult situation for the arts and entertainment industry. Art and entertainment, including the cinema, can only develop properly in a democratic society which also means that we can comment on and criticise society's taboos.

(Garin Nugroho was interviewed for Kinema by Jan Uhde in April 1999)

\section{Author Information}

Jan UHDE is Professor Emer. (Film Studies) at the University of Waterloo, Ontario, Canada. Born in Brno, Czech Republic. Graduated (MA) from the Faculty of Arts, Masaryk University, Brno; PhD received at the University of Waterloo, Ontario, Canada. He taught at the University of Waterloo (1970-2012) where he founded a General and Honours BA program in Film Studies at the Department of Fine Arts. 


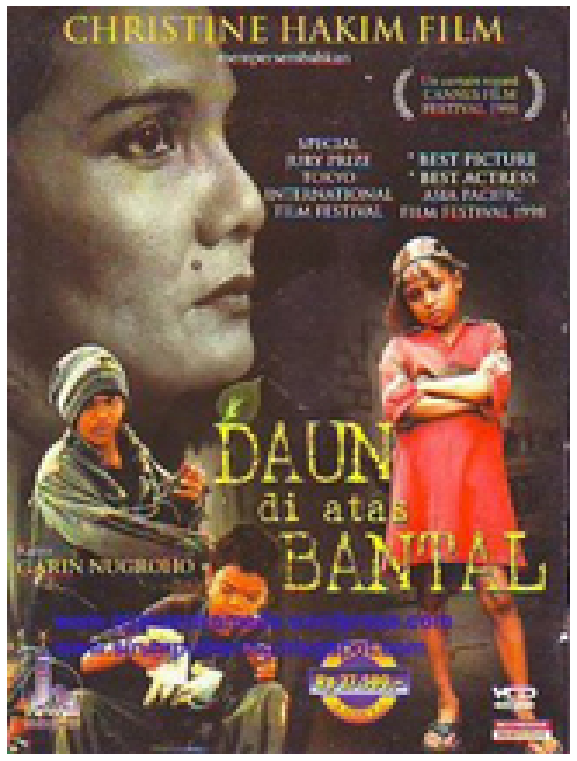

Figure 3: Leaf on a Pillow publicity poster

Publications: Latent Images: Film in Singapore Second edition, with Yvonne Ng Uhde (Ridge Books, National University Press of Singapore, 2010); Latent Images: Film in Singapore, with Yvonne Ng Uhde (Oxford University Press, 2000); Latent Images: Film in Singapore CD-ROM (2003, co-author); Vision and Persistence: Twenty Years of the Ontario Film Institute (University of Waterloo Press, 1990) and Ontario Film Institute Programming Activities Index 1969-1989 (Toronto: Ontario Science Centre, 1990). He co-edited the Place in Space: Human Culture in Landscape (Proceedings from the Second International Conference of the Working Group "Culture and Landscape" of the International Association of Landscape Ecology, Pudoc Scientific Publishers, Wageningen, Holland, 1993). Jan Uhde has published articles and reviews in several countries (including Canada, USA, Germany, Italy), participated in international juries at film festivals and presented papers at international conferences in North America and Europe. In 1998/99, he was a visiting researcher at the School for Film and Media Studies, Ngee Ann Polytechnic, Singapore.

His professional and research interests focus on Singapore cinema; the identification and distancing mechanisms of the film viewer; the non-authored modifications and manipulation of films; and specific aspects of film history, including the Central European cinema.

He founded KINEMA in 1993. 